\title{
FORMATION OF PROFESSIONAL MOTIVATION OF STUDENTS OF SPECIALTY "FOOD TECHNOLOGIES" IN THE PROCESS OF PRACTICAL TRAINING
}

Сьогодні багато фрахівців у галузі педагогіки
приділяють велику увагу формуванню про-
фесійної мотивації студентів. Мотивація
$\epsilon$ основним чинником, який визначає якість
і темп навчання. Профресійна мотивація,
на думку дослідників, визначає не тільки
правильність вибору подальшого профре-
сійного шляху, а і продуктивність трудової
діяльності, задоволеності результатами
праці та цілеспрямованість професійного
навчання. Необхідність підвищити рівень
просресійної мотивації в навчальних закладах
$\epsilon$ однією з головних цілей освіти.

Стаття присвячена проблемі формування профресійної мотивації студентів спеціальності «Харчові технології» у прочесі практичного навчання. Зокрема, висвітлено погляди вчених на різні аспекти та зміст чинників мотивації; модель фрормування профресійної мотивації та комплекс педагогічних умов ії ефрективного фрункціонування. З'ясовано значення виробничої практики як інструмента формування позитивного досвіду професійної діяльності. Особливу увагу приділено таким засобам практики, що впливають на ефективність процесу становлення мотивації до професійної діяльності, як вибір виробничих партнерів та робочого середовища, у якому усунені всі негативні чинники; керівництво практикою, участь у науково-практичних консреренціях за підсумками практичного навчання. Зазначається також, що ретельний відбір засобів практичного навчання впливає на результативність практики, позитивну мотивацію студентів до майбутньої професійної діяльності. Увага приділена дослідженню взаємозв'язку мотивації $i$ «Я-концепції» студента, а саме трьох ї складових частин: ідеального уявлення про себе, образу «Я» самооцінки. Обгрунтовані умови виробничоі практики, що забезпечують комплексний вплив на особистість студента у процесі виховання, навчання і становлення майбутнього фрахівия. Акцент зроблений на успішному розвитку сценарію формування профресійної мотивації у студентів у прочесі практичного навчання. Водночас наведені приклади інших сценаріїв становлення професійної мотивації студентів, у яких спостерігаються деякі ознаки розчарування у профресії, втрата інтересу до навчання і закономірне зниження професійної мотивації на різних курсах навчання.

Ключові слова: мотивація студентів, професійна мотивація студентів, практика, засобу практики, практичне навчання, Я-концепція студента.

Today, many pedagogical experts pay great attention to the formation of students' professional motivation. Motivation is the main factor that determines the quality and pace of learning. According to the researchers, professional motivation determines not only the correct choice of further career path, but also the productivity of work activity, satisfaction with the results of work and the purposefulness of vocational training. The need to increase the level of professional motivation in educational institutions is one of the main goals of education.

The article is devoted to the problem of formation of professional motivation of students of the specialty "Food Technologies" in the process of practical training. In particular, the views of scientists on various aspects and content of factors of motivation are covered; model of professional motivation formation and complex of pedagogical conditions of its effective functioning. The importance of industrial practice as a tool for forming a positive professional experience has been clarified. Particular attention is paid to such practices that affect the effectiveness of the process of becoming motivated to professional activity, as the choice of production partners and a work environment in which all the negative factors are eliminated; practice guidance, participation in scientific-practical conferences based on the results of practical training. It is also noted that careful selection of practical training means influences the effectiveness of practice, positive motivation of students for future professional activity. Attention is paid to the study of the relationship between student motivation and self-concept, namely its three components: perfect self-image, self-image and self-esteem. The substantiated conditions of industrial practice, providing a comprehensive impact on the individual on the student in the process of education, training and becoming a future specialist. Emphasis is placed on the successful development of the scenario of students' professional motivation formation in the process of practical training. At the same time, there are examples of other scenarios of students' professional motivation, which show some signs of frustration in the profession, loss of interest in learning and a natural decrease in professional motivation in different courses of study. Key words: student motivation, students' professional motivation, practice, means of practice, practical training, student's self-concept.
Постановка проблеми в загальному вигляді. Успішність реалізації завдань фрахової передвищої та вищої освіти багато в чому залежить від професійної мотивації студентів. Профресійна мотивація виступає внутрішнім рушійним чинником розвитку професіоналізму й особистості того, хто навчається, оскільки тільки на основі високого рівня розвитку мотивації можливе досягнення професійної освіченості й культури особистості.
Формування у студентів професійної мотивації визначає їхнє позитивне ставлення до майбутньої діяльності, прагнення створювати нові професійно вагомі цінності, задовольняти потреби в самореалізації й досягати профресійної майстерності. Особливої значущості набуває сорормованість профресійної мотивації для фрахівців такої галузі економіки, як ресторанне господарство. Без стійкої мотивації та орієнтації на успіх кожного 
фрахівця цієї сфрери неможливо забезпечити досягнення світових стандартів ресторанного сервісу.

Професійна мотивація як значущий результат підготовки студентів спеціальності «Харчові технології» не виникає стихійно і потребує цілеспрямованих, систематичних і погоджених дій з її формування. Ефективність фрормування профресійної мотивації у студентів потребує створення такого організаційно-освітнього середовища, яке б максимально сприяло задоволенню їхніх внутрішніх потреб та інтересів, а суттєвим потенціалом для успішного здійснення даного процесу володіє практичне навчання, яке є одним із найважливіших компонентів цілісної системи профресійного становлення фрахівців сорери ресторанного господарства. Практичне навчання, яке характеризується відносною автономністю і спрямованістю на опановування професійних компетенцій, сприяє фрормуванню мотивації в результаті занурення особистості в середовище профресійних дій. Воно дає можливість студентам своєчасно застосувати й апробувати здобуті знання зі спецдисциплін, оцінити свою здатність і готовність до професійної діяльності в реальних умовах. Тому особливо важливим стає питання про стимули і мотиви навчальнопрофресійної діяльності студентів.

Аналіз останніх досліджень і публікацій. Значущість обраного напряму доводить і науковопедагогічний інтерес до різних аспектів виявленої нами проблеми. Аналіз наукової та методичної літератури показує, що проблемам виявлення процесів професійної мотивації та вдосконалення методів її фрормування приділялася і зараз приділяється значна увага. Накопичено багатий досвід формування і розвитку мотивації студентів у сорері професійної діяльності, де в центрі уваги опинилися проблеми пошуку методів досягнення успіхів через активізацію пізнавального процесу.

Уперше слово «мотивація» ужив А. Шопенгауер у статті «Чотири принципи достатньої причини». Потім цей термін міцно увійшов у психологічний ужиток для пояснення причин поведінки людини.

Змістовні теорії мотивації, у яких учені концентруються на виявленні й аналізі змісту чинників мотивації, розробляли А. Маслоу, Д. Макклелланд, Х. Хекхаузер. У рамках процесного підходу до визначення категорії «мотивація» передусім необхідно виділити праці В. Асєєва, Дж. Аткінсона, В. Вілюнас, В. Врума, Е. Ільїна й інші. У роботах учених І. Бєляєвої, К. Обухівського, А. Леонтьєва, В. Рожина, П. Рудик, П. Якобсон розглядається процес фрормування і фрункціонування мотивації, виділяються мотиви трудової діяльності.

Різні автори зачіпають різні аспекти мотивації. П. Якобсон, К. Обухівський істотним моментом мотивації виділяють існування віддалених цілей, В. Вілюнас відносить до явищ мотивації будь-які приклади небайдужого ставлення живих істот до окремих дій.

У «Психологічному словнику» за редакцією А. Петровського та М. Ярошевського під мотивацією розуміються спонукання, що викликають активність організму і визначають її спрямованість. Ми дотримуємося розуміння поняття «мотивація» П. Якобсоном, який розглядає її як комплекс чинників, що спрямовують і спонукають поведінку людини, тобто як сукупність причин психологічного характеру, що пояснюють поведінку людини, її початок, спрямованість і активність. Формами прояву мотивів $€$ цілі, наміри, інтереси, емоції, інтерес до змісту і процесу діяльності, почуття обов'язку перед суспільством, професійне самовизначення, прагнення до самоствердження, самореалізації тощо.

Аналіз педагогічної літератури і потреби практики дозволили нам так сорормулювати проблему: яким чином реально здійснюється мотивація навчальної діяльності студентів спеціальності «Харчові технології» під час практичного навчання, як сприяти її формуванню?

Виділення не вирішених раніше частин загальної проблеми. Отже, вчені проявляють суттєвий інтерес до окремих аспектів виявленої проблеми, але питанням використання потенціалу практичного навчання для фрормування у студентів спеціальності «Харчові технології» професійної мотивації не приділялося достатньої уваги, що дозволяє вважати дану проблему актуальною для теорії профресійної підготовки.

Мета статті - теоретично обґрунтувати модель фрормування професійної мотивації й комплекс педагогічних умов ії ефективного фрункціонування під час проходження студентами практичного навчання.

Виклад основного матеріалу. Під професійною мотивацією розуміється дія конкретних спонукань, що обумовлюють вибір професії і тривале виконання обов'язків, пов'язанихіз цією професією. На думку М. Воробйової, професійна мотивація майбутнього фахівця являє собою сукупність стійких мотивів, прояв яких залежить від професійних поглядів, відносин, позицій, а також емоцій, почуттів, професійних якостей особистості [2, с. 8-9].

Ефективним способом вирішення проблеми фрормування профресійної мотивації у студентів вищих навчальних закладів $є$ посилення орієнтованого на практику характеру освіти, набуття успішного професійного досвіду в період навчання у виші. Головним інструментом формування позитивного досвіду професійної діяльності є студентська практика.

Практика виступає в єдності з теорією і пізнавальною діяльністю тих, хто навчається: студент як активний суб'єкт цілісного педагогічного процесу емпіричним шляхом пізнає світ профресії та фріксує значущі властивості і закономірності 
майбутньої просресійної діяльності. Студентська практика $€$ джерелом наукового і практичного пізнання, дає необхідний фрактичний матеріал, підлягає узагальненню і теоретичній обробці. Отримані у процесі практичного навчання знання використовуються як настанови до дії з перетворення дійсності та задоволення запитів майбутніх фахівців. Під час такого перетворення змінюється, вдосконалюється і розвивається «ідеальний» план підготовки студента до майбутньої профресії, зміцнюється професійна мотивація.

Структура практичного навчання представлена системою елементів, що взаємодіють: мета; доцільна діяльність, засоби діяльності, що використовуються у процесі реалізації мети; результати - продукти діяльності [1, с. 90].

Для нас становлять інтерес засоби практичної діяльності. До засобів практики можна віднести звітні конференції за підсумками практики, установчі збори студентів, виробниче середовище підприємств, співпрацю з керівником практики від підприємства, взаємодію $з$ керівником практики від навчального закладу й ін.

Важливо зазначити, що практика студентів пов'язана з діяльністю підприємств і, що найголовніше, з діяльністю інших людей, зачіпає їхні особисті та професійні інтереси, тоді як діяльність інших людей безпосередньо й опосередковано впливає на практичну діяльність кожного окремо взятого студента.

Організація практичного навчання студентів спеціальності «Харчові технології» показує, що до вибору виробничих партнерів, які організовують практику студентів фрахової передвищої освіти, потрібно ставитися ретельно і серйозно. Договори про співпрацю у сфрері профрільної підготовки студентів повинні укладатися з організаціями та підприємствами, які зарекомендували себе як профресіонали високого класу у своїй галузі. Це зазвичай підприємства, де створено особливе виробниче середовище. Особливе воно тому, що керівники підприємств велику увагу приділяють активізації в цьому середовищі внутрішніх мотивів співробітників, які змушують їх працювати з високим натхненням, робити максимально можливий внесок у справу підприємства.

Завдання навчального закладу як організатора практичного навчання студентів - запропонувати майбутнім фрахівцям таке робоче середовище, у якому будуть усунені всі негативні фрактори, а чинники професійної мотивації - максимально посилені. У такому середовищі у студентів з'являються внутрішні мотиви і стимули вносити в робочий процес підприємства найцінніше, на що вони здатні [5, с. 65]. Завдання навчального закладу - підібрати такі підприємства, де студенти зможуть максимально реалізувати свої професійні задатки і набути нових компетенцій.
Отже, вибір робочого середовища відіграє величезну роль у формуванні та становленні у студентів мотивації до професійної діяльності.

Говорячи про процес фрормування профресійної мотивації студентів, хотілося б підкреслити взаємозв'язок таких важливих понять, як «мотивація» і «Я-концепція» студента. «Я-концепція» студента - це його уявлення про себе, від яких залежить його ефективність у будь-який області діяльності, зокрема у профеесійному становленні.

Зміни й удосконалення в майбутній професії починаються зі змініполіпшенняуявлення студента про себе. Тому практичне навчання треба починати з того, щоби переконати студента, що в нього все вийде на роботі, що він може і готовий виконувати профресійні завдання. Це робиться на загальних установчих зборах із практики, які проводяться до початку практики. Але краще, щоби майбутні практиканти відвідали звітні консреренції за підсумками практики, які проводяться по закінченню виробничої практики, де старшокурсники представляють матеріали звітів із практики і науково-практичні виступи за підсумками професійного навчання.

Нагадаємо, що «Я-концепція» складається із трьох елементів: ідеального уявлення про себе, образу «я» і самооцінки [5, с. 72].

Консреренція за підсумками практики допомагає сформулювати ідеал, тобто студенти бачать i можуть співвіднести надії, мрії, прагнення і думки щодо профресійного майбутнього. Конфреренція можепосприятиусоормуванніідеальногопрофесійного «Я». Крім того, молоді люди схильні до впливу прикладів для наслідування, одного з найважливіших елементів ідеального уявлення про себе.

На консреренції за підсумками проходження практики має йтися про цінності, цілі та завдання професійного становлення, що важливо для формування ідеального уявлення студента про себе у профресії.

Наступна компонента «Я-концепції» - це образ «Я», тобто усвідомлення молодою людиною своїх якостей, цінностей і поведінки. Саме образ «Я» може визначити ефективність студента як майбутнього профресіонала.

У період становлення особистості на молоду людину істотно впливають слова і вчинки оточення. Важливо, щоби люди, які стикаються зі студентом на практиці, його колеги, поважали практиканта. Це також допоможе йому бути позитивним, приємним, людиною, з якою цікаво спілкуватися.

Образ «Я» студента поліпшується, коли його керівник частіше говорить, що той чудово виконав свою роботу, він зазначає, що його цінують i визнають значущість. Мотивація до професії стає більш стійкою, з'являється бажання розвиватися у своїй професії, вдумливо й результативно. Практикант слухає керівника практики, щоби зрозуміти, чи гарний він працівник, як справляється зі своїми 
завданнями і дорученнями, отже, саме керівник практики може суттєво вплинути на образ «Я» студента і практиканта. Керівник практики виступає для студента значущим дорослим, до якого прислухаються, чиї похвалу та визнання прагнуть заслужити, він не тільки носій інсрормації та вихователь, а й консультант, дослідник, експерт [4, с. 102].

Самооцінка студента, третя складова частина «Я-концепції», впливає на його професійне становлення як фрахівця. Студент 3 високою самооцінкою може бути креативним і продуктивним співробітником. В основі високої самооцінки - уміння подобатися собі. Чим більше студент подобається собі, тим вищі результати отримує в роботі. Самооцінка впливає на самоефективність.

Чим більше поведінка студента узгоджується 3 образом ідеального професійного «Я», чим більше він цінує себе як співробітника, тим більш профресійної особистістю він стає, успішніше проходить процес професійного становлення.

Вище йшлося про успішний розвиток сценарію формування мотивації до професійної діяльності у процесі практичного навчання студентів. Водночас практичне навчання студентів допомагає простежити й інші сценарії становлення професійної мотивації студентів.

Фахівці зазначають, що у процесі навчання у студентів найчастіше фрормуються окремі ознаки дезадаптації, які проявляються зниженням, аж до цілковитої втрати, мотивації до навчання і подальшої діяльності.

Наприклад, у частини студентів молодших курсів після першої виробничої практики відзначаються деяке розчарування у професії, втрата інтересу до навчання і закономірне зниження профресійної мотивації.

Зниження рівня профресійної мотивації у студентів у такому разі в основному має ситуативний характер. У період підготовки до виробничої практики відзначається погіршення фрункціонального стану, спричинене очікуванням практики. Уявлення студентів про взаємодію з персоналом підприємства викликають побоювання і тривогу в більшості студентів. Негативні очікування від майбутньої взаємодії з персоналом, необхідність адаптуватися в новому колективі, уявлення про реалізацію завдань практики та можливі труднощі провокують у студентів молодших курсів «редукцію професійних інтересів, знецінення діяльності майбутнього фрахівця і зниження значущості профресійних компетенцій».

Необхідно зазначити, що професійні інтереси більшості третьокурсників більшою мірою ситуативні, радше пов'язані з тематикою дисциплін, що вивчаються в поточному семестрі, ніж $€$ наслідком усвідомленого професійного вибору. Тому вибір баз практики не повинен здійснюватися студентами самостійно, переважно відпо- відно до їхніх власних інтересів, не враховуючи специоріки закладу, де вони будуть працювати під час практики. Отже, мотиваційні настанови щодо практичної діяльності студентів можуть більшою мірою визначатися очікуваннями від майбутньої практики, а не ступенем сорормованості їхніх професійних компетенцій.

Студенти старших курсів напередодні практики більш адаптовані до переходу на нову, практично спрямовану модель навчання. У них, з урахуванням уже наявного досвіду, немає труднощів із плануванням і структуруванням своєї практичної діяльності. Їх здебільшого турбує можлива невідповідність вимогам, що пред'являються до майбутнього фрахівця в ресторанній галузі, і недостатня сорормованість професійних компетенцій. Ревізія власних особистісних якостей, ступеня сорормованості практичних навичок і теоретико-методологічної підготовки може негативно позначатися на рівні мотивації до професійної діяльності. Основним мотивом для вибору практики може бути максимальне виключення ймовірності демонстрації професійної некомпетентності. Отже, мотиваційні настанови студентів старших курсів більшою мірою залежать від їхньої суб'єктивної оцінки сорормованості профресійних компетенцій і експертних оцінок.

На завершальному етапі навчання студентів спеціальності «Харчові технології» актуальними стають зіставлення бажаного і досягнутого рівнів професійних компетенцій, а також самостійне визначення подальшого професійного шляху. Найчастіше результати такого реслексивного аналізу також призводять до зниження рівня просресійної мотивації.

У студентів старших курсів може спостерігатися зниження мотиваційних настанов і в ситуації відсутності професійного самовизначення. Студенти, які мають більш чіткі уявлення про напрям і місце майбутньої діяльності як спеціаліста (після закінчення навчального закладу), не маніфрестують зниження мотивації до практичної діяльності. Водночас у студентів, які не мають чітких професійних уявлень і планів, спостерігається зниження мотивації і розчарування у власному професійному виборі.

3 метою фрормування мотиваційних настанов щодо практичної діяльності та розвитку профресійних якостей майбутніх фрахівців пропонується проводити динамічний психолого-педагогічний моніторинг мотиваційних настанов студентів на різних етапах навчання; підтримувати студентів, які відчувають труднощі професійного навчання і демонструють зниження за професійним спрямуванням; актуалізувати мотиваційні настанови на практичну діяльність майбутніх фахівців шляхом проведення тренінгів і психолого-педагогічних занять, спрямованих на збереження і підсилення мотиваційних настанов на подальшу професійну діяльність як 
фрахівця з обраної професії, розвиток необхідних для успішної профресійної діяльності особистісних властивостей і якостей.

Висновки. Отже, практичне навчання як обов'язковий компонент освітнього процесу відіграє важливу роль у формуванні в майбутнього фрахівця стійкої мотивації до здійснення професійноїдіяльності. Ретельнийвідбірзасобівпрактичного навчання забезпечує цілісність, високу результативність практики, позитивну мотивацію до майбутньої професійної діяльності, сприяє формуванню сучасного типу професійної поведінки студентів.

\section{БІБЛІОГРАФІЧНИЙ СПИСОК:}

1. Бороненко Т., Федотова В. Содержание педагогической практики бакалавров и магистрантов направления «Педагогическое образование». Вестник Балтийского федерального университета им. И. Канта. Калининград, 2014. Вып. 11. С. 87-101.
2. Воробьева М. Развитие профессиональной мотивации студентов в процессе обучения в туристском вузе : авторефр. дис. ... канд. пед. наук. Сходня, 2010. 24 c.

3. Дулинец Т., Захарова А. Исследование учебной мотивации студентов. Педагогика высшей школы. 2017. № 2. С. 4-6.

4. Смирнова Л., Самусева А. Инновационная модель образовательной системы в высшей школе России. Современные тенденции и инновации в науке, образовании и бизнесе: материалы пленарного и секционного заседаний IX Научнопрактической консреренции с международным участием, 15-19 апреля 2013 г. : в 4-х т. Т. III / под ред. Н. Чернер. Одинцово : АНОО ВПО ОГИ, 2013. C. 100-104.

5. Трейси Б. Полная вовлеченность. Вдохновляйте, мотивируйте и раскрывайте всё лучшее в своей команде. Пер. с англ. М. Яцюк. Москва : Манн, Иванов и Фербер, 2016. 272 с. 